\title{
Kajian Arsitektur Vernakular dan Ramah Lingkungan pada Gedung Kampus Universitas Mataram
}

Teti Handayani ${ }^{1}$ Rini S. Saptaningtyas ${ }^{1}$, Zaedar Gazalba ${ }^{1}$, Giska Pradana Ayu Putri Kamase ${ }^{1}$, Jasmine Chanifah Uzdah Bachtiar $^{1}$, Ni Ketut Ayu Intan Putri Mentari Indriani ${ }^{1}$

${ }^{1}$ Program Studi Arsitektur, Fakultas Teknik, Universitas Mataram

Jalan Majapahit No. 62, Kota Mataram, NTB

*Email: Tetyhandayani@gmail.com

\begin{abstract}
Abstrak
Perkembangan tampilan gedung-gedung baru di lingkungan Universitas Mataram satu dekade terakhir menampakkan adanya pergeseran ke arah bentuk dan material kekinian yang menghasilkan fasade/tampilan sangat berbeda dengan gedung-gedung yang ada sebelumnya. Hal ini menghadirkan kekhawatiran bila dibiarkan berkelanjutan maka Universitas Mataram sebagai salah satu perguruan tinggi negeri di Nusa Tenggara Barat akan kehilangan jati diri atau identitasnya. Penelitian ini bertujuan untuk mengkaji ciri atau kriteria arsitektur vernakular dan ramah lingkungan yang dapat diterapkan pada gedung kampus Universitas Mataram dan mengevaluasinya pada gedung lama dan gedung baru. Penelitian ini menggunakan metode kualitatif, dengan mengkaji literatur dan mengevaluasi bangunan berdasarkan kriteria yang didapatkan. Gedung perpustakaan mewakili gedung lama dan gedung Fisipol mewakili gedung baru sebagai gedung-gedung yang dikaji. Analisis data dilakukan secara deskriptif kualitatif. Hasil menunjukkan bahwa gedung perpustakaan dan Fisipol memenuhi kriteria atau ciri arsitektur vernakular yang sama walau secara visual keduanya tampak berbeda. Akan tetapi, gedung perpustakaan memenuhi kriteria arsitektur ramah lingkungan lebih banyak dibandingkan dengan gedung Fisipol yang merupakan bangunan baru. Kajian ini diharapkan dapat meningkatkan penelitian arsitektur vernakular sebagai identitas kampus-kampus baru di Indonesia. Penelitian ini masih banyak kekurangan sehingga membutuhkan lebih banyak kajian yang serupa.
\end{abstract}

Kata kunci: arsitektur ramah lingkungan, arsitektur vernakular, identitas kampus, Universitas Mataram

\begin{abstract}
In the last decade, the development of new buildings in Mataram University has shown a shift towards contemporary forms and materials which results a quite different facade / appearance from the existing buildings. The situation raises an awareness that if it is allowed to continue, Mataram University as one of the state universities in West Nusa Tenggara will lose its identity. This study aims to examine the characteristics of vernacular and environmentally friendly architecture that can be applied to Mataram University's building and evaluate it in the old and new buildings. This study uses a qualitative method, by reviewing the literature and evaluating the building based on the criteria obtained. The library building represents the old building and the Fisipol building represents the new building as subjects studied. Data analysis was done by descriptively qualitatively. The results show that the library building and Fisipol meet the same criteria or vernacular architectural characteristics even though visually the buildings look different. However, the library building meets the criteria for environmentally friendly architecture compared to Fisipol building, which is a new building. This study is expected to increase research on vernacular architecture as the identity of new campuses in Indonesia. This research still has many shortcomings, therefore it requires more similar studies in the future.
\end{abstract}

Kata kunci: eco-friendly architecture, vernacular architecture, campus identity, Mataram University

\section{Pendahuluan}

Arsitektur adalah sebuah ciptaan manusia yang merupakan suatu artefak budaya hasil dari peradaban manusia. Perkembangannya didasari oleh perkembangan kebudayaan manusia dalam arti luas termasuk di dalamnya teknologi (Suriastuti et al., 2014). Karya arsitektur mencerminkan identitas suatu masyarakat yang memuat pesan, konsep, dan karakter penggunanya sehingga akan sangat bergantung pada geografi, tradisi, budaya, adat istiadat, sejarah dan pengetahuan pada masa itu (Torabi \& Brahman,
2013). Cerminan identitas melalui karya arsitektur dapat dilakukan dengan menonjolkan aspek fisik, seperti alam, lingkungan sekitar, bentuk, ukuran, dekorasi, konstruksi dan sebagainya, atau dapat pula dilakukan dengan menonjolkan aspek fungsi, warisan dan sejarah (Ghotbi, 2008).

Desain kampus yang tepat harus mencerminkan karakter, citra, dan identitas universitas, serta gambaran kualitas kegiatan belajar mengajar yang ditawarkan. Ketepatan tersebut dicapai dengan menangani dan memecahkan masalah kelestarian dan perubahan pada elemen-elemen fisik dan bentuk 
(Dober, 1991). Identitas atau karakter inilah yang akan membedakan kampus yang satu dengan kampus lainnya.

Keputusan Universitas Mataram untuk melakukan pengembangan kawasan ataupun penambahan gedung baru merupakan langkah untuk membentuk jati diri ataupun citra yang baru. Hal ini bukan berarti menghapus sejarah atau nilai historis yang dimiliki, melainkan pembentukan identitas baru dengan menghargai arsitektur sebagai perwujudan dari nilainilai yang dianut institusi. Penggabungkan area konservasi yang bernilai historis dengan area modern yang menjawab perkembangan jaman perlu diperhatikan dengan seksama untuk memastikan pengembangan kawasan yang harmonis.

Untuk menjawab tantangan tersebut kita dapat memilih untuk mengikuti arus gelombang modernisasi dengan tetap berusaha untuk tidak meninggalkan jati diri yang kita miliki. Warisan budaya, sejarah, serta potensi lokal yang dimiliki perlu diperhatikan, salah satunya melalui penerapan arsitektur vernakular. Peran arsitektur vernakular menjadi makin penting karena arsitektur ini merupakan bagian dari jejak sejarah yang merekam gaya hidup dan warisan budaya masyarakatnya (Pearson, 1994).

Modernisasi dan kemajuan teknologi serta interaksi sosial ekonomi menuntut kehadiran arsitektur yang mampu berdialog dengan tuntutan baru. Sinkretisme arsitektur vernakular Indonesia merupakan potensi yang memberi sumbangan pada "Post Modernisme" dalam tampilan arsitektur "Neo-Vernakular". Dengan demikian diharapkan Arsitektur Vernakular menjadi salah satu jembatan menuju evolusi arsitektur Indonesia modern yang tetap berjati diri dan berakar pada tradisi (Wiranto, 1999).

Penerapan makna dan peran inovasi arsitektur vernakular dalam pengembangan kampus Universitas Mataram mendorong terciptanya tampilan yang modern namun tetap memiliki kepribadian khas dengan berlandaskan lokalitas. Prinsip lokalitas inilah yang nantinya akan dapat ditransformasikan ke dalam bentuk-bentuk yang lebih modern sesuai dengan perubahan tatanan sosial masa kini.

Arsitektur vernakular juga mengacu pada kondisi, potensi iklim, budaya dan keadaan masyarakat lingkungannya, sehingga sarat akan nilai arsitektonis dan ekologis yang tanggap terhadap lingkungan (Papanek, 1995). Dengan berkembang pesatnya isu pemanasan global, maka Universitas Mataram perlu berkontribusi untuk menghasilkan bangunan yang responsif terhadap lingkungannya. Harapannya, kajian ini akan menghasilkan desain bangunan yang ramah lingkungan dan minim pemakaian energi.

\section{Metode Penelitian}

Penelitian dilakukan dengan metode kualitatif dimana data dikelompokkan menjadi data fisik dan non fisik. Data fisik diperoleh dengan pengamatan dan rekaman foto, serta penelusuran dokumen, sedangkan data non fisik diperoleh melalui Focus Group Discussion $(F G D)$. Analisis data dilakukan secara deskriptif berdasar pada bukti empiris dan interpretatif melalui kajian semiotika untuk membaca elemen arsitektur pada arsitektur masa kini yang dijadikan sebagai objek komparasi/preseden dan elemen bahasa rupa pada arsitektur vernakular pada kampus Universitas Mataram.

\section{Pembahasan}

\section{Perkembangan Kampus Universitas Mataram}

Universitas Mataram resmi berdiri pada tanggal 18 Desember 1963 dengan Surat Keputusan Presiden RI No. 257/1963, yang dinyatakan berlaku terhitung mulai tanggal 1 Oktober 1962 (Renstra Universitas Mataram tahun 2020-2024). Selama kurun waktu 1962 - 2021, Universitas Mataram telah mengalami berbagai tahap pengembangan.

Mencermati perkembangan arsitektur gedung di lingkungan kampus Universitas Mataram tampak perubahan yang cukup mencolok satu dekade terakhir, baik dari fasade maupun bentuk bangunannya. Bentuk bangunan yang makin disederhanakan, dengan material fasade yg modern mulai digemari. Tampak kebebasan dalam mengekspresikan nilai-nilai estetika dalam berarsitektur, menggeser kaidah-kaidah "kelokalan" yg telah terimplementasi bertahun-tahun pada gedung-gedung kampus Universitas Mataram. Gedung Prodi Ilmu Kelautan, gedung Fisipol, gedung Farmasi, serta gedung Pasca Sarjana, memiliki fasade dan bentuk yang berbeda.

\section{Kajian Kampus di Indonesia yang Menerapkan Arsitektur Vernakular}

Arsitektur vernakular adalah arsitektur yang dibangun oleh masyarakat setempat sehingga prinsipprinsip desain bangunan telah sesuai dengan karakter masyarakat dan kondisi lingkungan setempat. Beberapa bangunan di Indonesia ada yang mengadopsi prinsip bangunan arsitektur vernakular untuk dijadikan sebagai penanda kedaerahan tertentu melalui bentuk, warna, tekstur, ornament, dan sebagainya. Pada bangunan kampus-kampus di Indonesia, terdapat beberapa pola pola adaptasi arsitektur vernakular yang telah diterapkan pada desain bangunan (Gambar 1 dan 2).

Kampus ITB adalah salah satu kampus tertua di Indonesia dan bangunan tertuanya adalah Aula Timur 
dan Aula Barat. Kedua bangunan ini didesain oleh Henri MacLaine Pont yang berkebangsaan Belanda. Desain kedua bangunan ini sangat menarik karena terlihat harmonisasi perpaduan desain arsitektur vernakular pada bagian atapnya dan arsitektur kolonial Belanda pada bagian gedungnya. Akan tetapi, desain arsitektur atap bangunan tersebut sulit ditelaah asal muasalnya dan telah ada beberapa penelitian terdahulu yang mengkaji desain atap tersebut. Menurut Sitorus (2017), atap kedua bangunan tersebut mengadopsi arsitektur vernakular Sunda kuno dan bukan dari Minangkabau. Atap bangunan Minangkabau terlihat sama dan bertumpuk seperti kedua gedung aula, akan tetapi kontruksi atap yang digunakan berbeda (Sitorus, 2017).

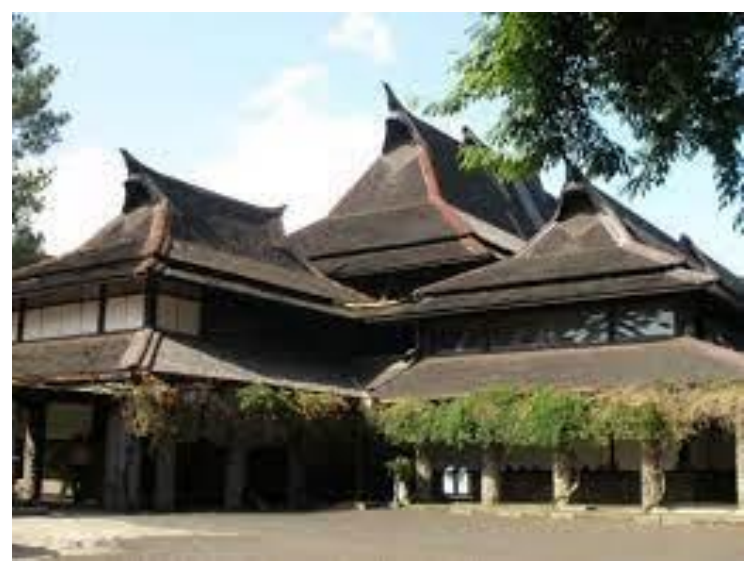

Gambar 1. Arsitektur Vernakular Kampus ITB Sumber: Asyraf \& Budi, 2017

Aula Timur dan Barat menggunakan konstruksi pelana dan kuda-kuda miring. Berbeda dengan Sitorus, Asyraf \& Budi (2017) berhasil menggabungkan berbagai perspektif asal usul desain arsitektur atap gedung Aula Timur di ITB. Berdasarkan berbagai sumber, atap bangunan dapat berasal dari arsitektur vernakular Kampung Papandak, Minangkabau, Batak Karo, dan juga Sunda. Berbagai interpretasi ini disebabkan oleh bentuk atap yang menjulang tinggi dengan tritisan atap yang banyak digunakan oleh bangunan arsitektur vernakular di Indonesia (Asyraf \& Budi, 2017).

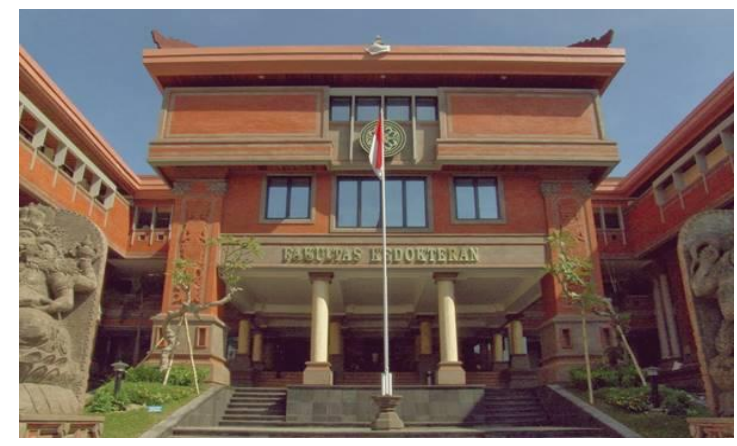

Gambar 2. Arsitektur Vernakular Kampus Udayana Sumber: Amira, 2021
Selain ITB, kampus lain di Indonesia yang menerapkan arsitektur vernakular adalah Universitas Udayana (Unud) Bali. Penerapan langgam arsitektur vernakular Bali dapat dilihat pada beberapa elemen bangunan kampus Unud. Hal ini juga di atur dalam Rencana Induk Pengembangan Fisik Universitas Udayana. Penerapan langgam arsitektur vernakular Bali pada tampilan bangunan kampus Universitas Udayana mengacu pada beberapa unsur arsitektur vernakular Bali antara lain wujud, warna, material dan ornamen yang dapat ditemukan pada sebagaian besar bangunan di kampus tersebut. Salah satu penerapan arsitektur vernakular bali ada pada penerapan konsepsi Tri Angga dalam wujud bangunannya.

Konsep arsitektur vernakular Bali berkaitan dengan simbolisasi hubungan manusia sebagai unsur mikrokosmos (bhuwana alit) dan makrokosmos (bhuwana agung). Makrokosmos dalam Tri Loka terdiri atas Swah Loka (alam atas / alam para dewa), Bwah Loka (alam tengah / alam manusia) dan Bhur Loka (alam bawah / Bhuta Kala). Sementara manusia disetarakan sebagai unsur mikrokosmos yang dalam konsep Tri Angga digambarkan dengan tiga pembagian struktur tubuh meliputi kepala, tubuh, dan kaki. Konsep Tri Angga diimplementasikan pada bidang vertikal dalam bangunan rumah tinggal, meliputi atap bangunan sebagai simbolisasi struktur kepala; dinding dan tiang (saka) bangunan mewakili struktur tubuh; pondasi, bebaturan serta lantai bangunan mewakili bagian struktur kaki (Raharja, 2010). Sementara pada unsur warna dan material dapat dilihat dari dominasi penggunaan bata merah yang ada pada beberapa bangunan di kampus Universitas Udayana yang mewakili karakter arsitektur vernakular Bali. Selain pada bangunan gedung, penerapan arsitektur vernakular Bali juga dapat dilihat dari desain gerbang yang mengadopsi bentuk candi bentar, maupun detail ukiran pada bangunan serta sistem petanda yang ada pada areal kampus juga mendapat sentuhan ornamenasi arsitektur vernakular Bali.

\section{Interpretasi Ciri Vernakular pada Gedung Kampus Universitas Mataram}

Berdasarkan studi pustaka yang telah dilakukan sebelumnya, ciri vernakular banyak ditemukan di bangunan tradisional atau bangunan hunian di beberapa wilayah Indonesia. Akan tetapi, bangunan pendidikan di Indonesia juga ada yang mengadaptasi ciri fisik vernakular bangunan setempat seperti ITB dan Universitas Udayana. Ciri vernakular menjadi karakteristik unik bangunan kampus sehingga kampus memiliki identitas tertentu, berbeda dengan bangunan kampus lain yang cenderung memiliki ciri modern pada fasadnya. 
Untuk mengevaluasi bangunan kampus Universitas Mataram, Peneliti merujuk pada bangunan di Desa Sade yang terletak di Kecamatan Pujut Kabupaten Lombok Tengah yang karakteristik arsitektur vernakular Lombok-nya dapat dilihat dari rumah adat Desa Sade yang masih terjaga hingga hari ini.

Beberapa ciri fisik bangunan di Desa Sade yang dapat diinterpretasikan untuk bangunan modern harus dikaji terlebih dahulu. Atap, dinding, dan lantai adalah elemen pelingkup bangunan yang dapat diidentifikasi dalam fisik, bentuk, dan material. Sementara itu, aspek makna vernakular Sade tidak dapat diterjemahkan secara langsung sehingga aspek makna tidak diikutsertakan dalam indikator penelitian ini. Penerjemahan aspek fisik bangunan Sade ke bangunan modern dapat dilihat dalam Tabel 1 berikut.

Tabel 1. Interpretasi Ciri Vernakular pada Bangunan Kampus

\begin{tabular}{|c|c|c|c|}
\hline \multicolumn{2}{|c|}{$\begin{array}{c}\text { Faktor-Faktor } \\
\text { Bangunan }\end{array}$} & $\begin{array}{l}\text { Ciri Vernakular } \\
\text { Bangunan Sade }\end{array}$ & $\begin{array}{c}\text { Interpretasi Ciri } \\
\text { Vernakular }\end{array}$ \\
\hline \multirow[b]{2}{*}{ 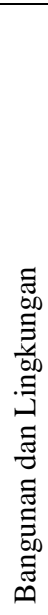 } & 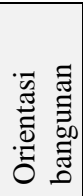 & $\begin{array}{l}\text { Orientasi ke timur } \\
\text { dan barat (Krisna et } \\
\text { al., 2005) }\end{array}$ & $\begin{array}{l}\text { Bukaan } \\
\text { bangunan } \\
\text { menghadap } \\
\text { orientasi timur } \\
\text { dan barat }\end{array}$ \\
\hline & 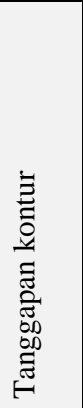 & $\begin{array}{l}\text { Bangunan disusun } \\
\text { mengikuti kontur ke } \\
\text { arah Gunung Rinjani, } \\
\text { semakin tinggi letak } \\
\text { bangunan maka } \\
\text { semakin tinggi } \\
\text { kedudukan/hierarki } \\
\text { tempat (Auliya et al., } \\
\text { 2009) }\end{array}$ & $\begin{array}{l}\text { Bangunan } \\
\text { disusun } \\
\text { mengikuti arah } \\
\text { kontur, } \\
\text { bangunan yang } \\
\text { kedudukannya } \\
\text { tinggi } \\
\text { ditempatkan di } \\
\text { tempat yang } \\
\text { lebih tinggi } \\
\text { (secara kontur) }\end{array}$ \\
\hline \multirow[b]{3}{*}{ 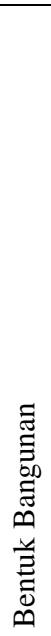 } & \multirow[b]{2}{*}{ 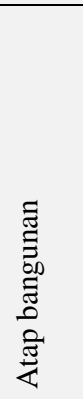 } & $\begin{array}{l}\text { Atap bangunan } \\
\text { cenderung dibuat } \\
\text { lebih lebar } \\
\text { (Anggraeny et al., } \\
\text { 2011) }\end{array}$ & $\begin{array}{l}\text { Lebar atap dapat } \\
\text { melindungi } \\
\text { dinding } \\
\text { bangunan }\end{array}$ \\
\hline & & $\begin{array}{l}\text { Atap bangunan } \\
\text { berbentuk lumbung } \\
\text { sebagai tempat } \\
\text { penyimpanan hasil } \\
\text { pertanian }\end{array}$ & $\begin{array}{l}\text { Atap lumbung } \\
\text { sebagai fungsi } \\
\text { penyimpanan }\end{array}$ \\
\hline & 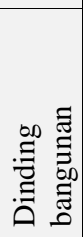 & $\begin{array}{l}\text { Dinding rumah } \\
\text { cenderung menutupi } \\
\text { seluruh rumah tanpa } \\
\text { adanya jendela } \\
\text { (Anggraeny et al., } \\
\text { 2011) }\end{array}$ & $\begin{array}{l}\text { Dinding dapat } \\
\text { melindungi } \\
\text { bangunan }\end{array}$ \\
\hline
\end{tabular}

\begin{tabular}{|c|c|c|c|}
\hline \multicolumn{2}{|c|}{$\begin{array}{c}\text { Faktor-Faktor } \\
\text { Bangunan }\end{array}$} & \multirow{2}{*}{$\begin{array}{l}\text { Ciri Vernakular } \\
\text { Bangunan Sade } \\
\text { Tidak ada jendela, } \\
\text { hanya ada celah- } \\
\text { celah kecil pada } \\
\text { anyaman bambu } \\
\text { untuk masuknya } \\
\text { cahaya (Anggraeny } \\
\text { et al., 2011) }\end{array}$} & \multirow{2}{*}{$\begin{array}{l}\text { Interpretasi Ciri } \\
\text { Vernakular } \\
\text { Memiliki } \\
\text { bukaan kecil dan } \\
\text { banyak }\end{array}$} \\
\hline & 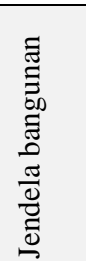 & & \\
\hline & 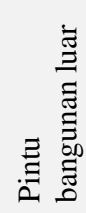 & $\begin{array}{l}\text { Pintu terbuat dari } \\
\text { anyaman bambu } \\
\text { (Anggraeny et al., } \\
\text { 2011) }\end{array}$ & $\begin{array}{l}\text { Pintu dapat } \\
\text { dibuka dan tidak } \\
\text { tembus pandang }\end{array}$ \\
\hline & 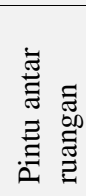 & $\begin{array}{l}\text { Pintu berupa pintu } \\
\text { geser (Anggraeny et } \\
\text { al., 2011) }\end{array}$ & $\begin{array}{l}\text { Pintu dapat } \\
\text { digeser }\end{array}$ \\
\hline & & $\begin{array}{l}\text { Lantai ditinggikan } 50 \\
\text { cm dari permukaan } \\
\text { tanah (Anggraeny et } \\
\text { al., 2011) }\end{array}$ & $\begin{array}{l}\text { Ada kenaikan } \\
\text { lantai dari area } \\
\text { sekitar }\end{array}$ \\
\hline & 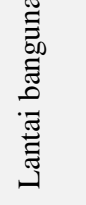 & $\begin{array}{l}\begin{array}{l}\text { Ketinggian tempat } \\
\text { duduk dari tanah } \\
\text { sekitar } 80 \mathrm{~cm}\end{array} \\
\begin{array}{l}\text { (beruga') (Pujianto } \\
\text { \& Yenny, 2017) }\end{array}\end{array}$ & \\
\hline \multirow[b]{5}{*}{ 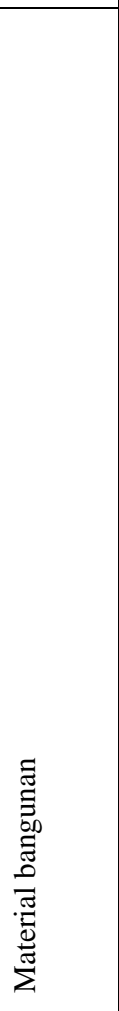 } & ฮี & $\begin{array}{l}\text { Atap dengan } \\
\text { menggunakan } \\
\text { material alang-alang } \\
\text { kering (Anggraeny et } \\
\text { al., 2011) }\end{array}$ & $\begin{array}{l}\text { Menggunakan } \\
\text { material tidak } \\
\text { panas dan } \\
\text { mudah } \\
\text { didapatkan }\end{array}$ \\
\hline & 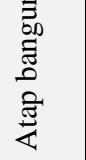 & $\begin{array}{l}\text { Atap menggunakan } \\
\text { material ijuk } \\
\text { (beruga') (Pujianto } \\
\text { \& Yenny, 2017) }\end{array}$ & \\
\hline & 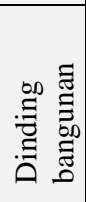 & $\begin{array}{l}\text { Dinding bangunan } \\
\text { terbuat dari anyaman } \\
\underline{\text { bambu }}\end{array}$ & $\begin{array}{l}\text { Menggunakan } \\
\text { material ramah } \\
\text { lingkungan }\end{array}$ \\
\hline & 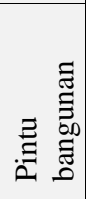 & $\begin{array}{l}\text { Pintu terbuat dari } \\
\text { anyaman bambu } \\
\text { (Anggraeny et al., } \\
\text { 2011) }\end{array}$ & $\begin{array}{l}\text { Menggunakan } \\
\text { material ramah } \\
\text { lingkungan }\end{array}$ \\
\hline & 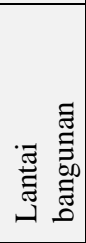 & $\begin{array}{l}\text { Lantai terbuat dari } \\
\text { campuran tanah liat, } \\
\underline{\text { abu jerami dan }} \\
\text { kotoran kerbau } \\
\text { (Anggraeny et al., } \\
\text { 2011) }\end{array}$ & $\begin{array}{l}\text { Menggunakan } \\
\text { material ramah } \\
\text { lingkungan }\end{array}$ \\
\hline 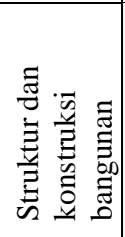 & 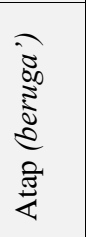 & $\begin{array}{l}\text { Menggunakan atap } \\
\text { perisai dengan } \\
\text { konstruksi bilah } \\
\text { bambu (beruga') } \\
\text { (Pujianto \& Yenny, } \\
\text { 2017) }\end{array}$ & $\begin{array}{l}\text { Menggunakan } \\
\text { konstruksi atap } \\
\text { ringan dengan } \\
\text { bentuk perisai }\end{array}$ \\
\hline
\end{tabular}




\begin{tabular}{|c|c|c|}
\hline $\begin{array}{c}\text { Faktor-Faktor } \\
\text { Bangunan }\end{array}$ & $\begin{array}{l}\text { Ciri Vernakular } \\
\text { Bangunan Sade }\end{array}$ & $\begin{array}{c}\text { Interpretasi Ciri } \\
\text { Vernakular }\end{array}$ \\
\hline 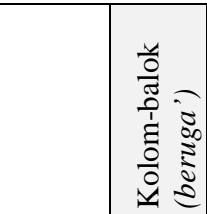 & $\begin{array}{l}\text { Kolom dan balok } \\
\text { disambung dengan } \\
\text { menggunakan pola } \\
\text { pasak (Pujianto \& } \\
\text { Yenny, 2017) }\end{array}$ & $\begin{array}{l}\text { Menggunakan } \\
\text { konstruksi } \\
\text { ringan yang } \\
\text { tidak kaku }\end{array}$ \\
\hline
\end{tabular}

Arsitektur vernakular memiliki bentuk adaptasi terhadap iklim setempat yang dapat dilihat pada fisik bangunan sehingga dapat bertahan keberadaannya selama ratusan tahun. Beberapa bentuk adaptasi bangunan Sade telah dikaji sebelumnya sehingga interpretasi terhadap bangunan kampus perlu dilakukan sebagai bahan evaluasi bangunan. Bangunan tradisional pada umumnya menggunakan konsep arsitektur ramah lingkungan karena masyarakat tradisional hidup selaras dengan alam sehingga apa yang dimanfaatkan saat ini akan dikembalikan ke alam lagi. Oleh karena itu, beberapa bentuk adaptasi bangunan tradisional Sade (arsitektur rendah energi) yang dapat diterjemahkan untuk bangunan modern dengan fungsi yang berbeda dapat dilihat pada Tabel 2 .

Tabel 2. Interpretasi Arsitektur Rendah Energi pada Bangunan Kampus

\begin{tabular}{|c|c|c|}
\hline \multicolumn{2}{|c|}{$\begin{array}{l}\text { Faktor-Faktor } \\
\text { Bangunan }\end{array}$} & Penerapan Bangunan Kampus \\
\hline \multirow{5}{*}{ 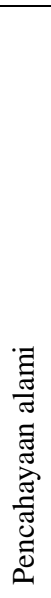 } & \multirow{2}{*}{ 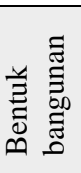 } & $\begin{array}{l}\text { Bangunan yang ramping agar cahaya } \\
\text { matahari dapat tersebar secara merata }\end{array}$ \\
\hline & & Bangunan dibuat bermassa \\
\hline & $\stackrel{\infty}{:}$ & $\begin{array}{l}\text { Bukaan maupun jendela sebagai sumber } \\
\text { masuknya cahaya }\end{array}$ \\
\hline & 苂 & $\begin{array}{l}\text { Pengadaan skylight jika bangunan tidak } \\
\text { memungkinkan dirancang secara } \\
\text { ramping }\end{array}$ \\
\hline & 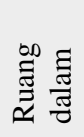 & $\begin{array}{l}\text { Pengadaan courtyard di tengah } \\
\text { bangunan jika perancangan bangunan } \\
\text { yang ramping tidak memungkinkan }\end{array}$ \\
\hline \multirow{3}{*}{ 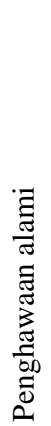 } & 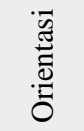 & $\begin{array}{l}\text { Orientasi bangunan yang } \\
\text { memanfaatkan arah angin }\end{array}$ \\
\hline & \multirow{2}{*}{ 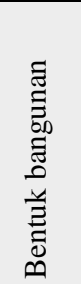 } & $\begin{array}{l}\text { Bangunan yang ramping dan } \\
\text { membentang untuk memaksimalkan } \\
\text { aliran udara dan mendorong terjadinya } \\
\text { sistem ventilasi silang }\end{array}$ \\
\hline & & $\begin{array}{l}\text { Bangunan dibuat bermassa untuk } \\
\text { mendorong sirkulasi udara antar } \\
\text { bangunan }\end{array}$ \\
\hline
\end{tabular}

\begin{tabular}{|c|c|c|}
\hline \multicolumn{2}{|c|}{$\begin{array}{c}\text { Faktor-Faktor } \\
\text { Bangunan }\end{array}$} & Penerapan Bangunan Kampus \\
\hline & \multirow{2}{*}{$\stackrel{\infty}{\Xi}$} & $\begin{array}{l}\text { Bukaan maupun jendela sebagai sumber } \\
\text { masuknya penghawaan alami }\end{array}$ \\
\hline & & $\begin{array}{l}\text { Posisi bukaan yang memungkinkan } \\
\text { sistem ventilasi silang }\end{array}$ \\
\hline & 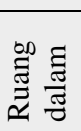 & $\begin{array}{l}\text { Pengadaan courtyard di tengah } \\
\text { bangunan jika perancangan bangunan } \\
\text { yang ramping tidak memungkinkan }\end{array}$ \\
\hline \multirow{3}{*}{ 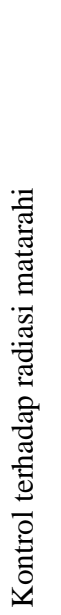 } & 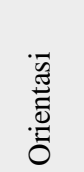 & $\begin{array}{l}\text { Menghindari orientasi langsung ke sisi } \\
\text { timur dan barat untuk mereduksi radiasi } \\
\text { matahari yang tinggi }\end{array}$ \\
\hline & 苂 & $\begin{array}{l}\text { Penambahan teritisan atap sebagai } \\
\text { pembayang maupun elemen peneduh }\end{array}$ \\
\hline & $\stackrel{\infty}{\stackrel{\infty}{\leftrightarrows}}$ & $\begin{array}{l}\text { Penambahan elemen peneduh (sun } \\
\text { shading devices) pada area bukaan } \\
\text { maupun jendela, baik berupa konsol, } \\
\text { overhang, removable shading dan } \\
\text { lainnya. Metode ini khususnya } \\
\text { diterapkan pada bukaan/jendela yang } \\
\text { menghadap langsung ke sisi timur dan } \\
\text { barat }\end{array}$ \\
\hline
\end{tabular}

Berdasarkan Tabel 1 dan Tabel 2, ciri vernakular secara fisik dan arsitektur ramah lingkungan dapat diidentifikasi secara visual pada bangunan kampus. Untuk mengetahui lebih dalam mengenai penerapannya pada bangunan, maka bangunan Perpustakaan dan Gedung Fisipol digunakan sebagai sampel bangunan yang merepresentasikan bangunan lama dan baru di Universitas Mataram. Tinjauan mengenai ciri vernakular dan arsitektur ramah lingkungan akan dibahas lebih dalam untuk menganalisis penerapan ciri-ciri tersebut pada bangunan kampus.

\section{Profil Gedung Perpustakaan}

Gedung perpustakaan Universitas Mataram sebelumnya terletak di Jalan Pendidikan Mataram dekat dengan rektorat lama, masih berupa ruang kecil dengan fasilitas terbatas. Namun kini, Perpustakaan Universitas Mataram menempati gedung tiga lantai yang telah dilengkapi dengan sistem informasi pendukung untuk mengakses bacaan dan publikasi yang lebih luas.

Koleksi Perpustakaan Universitas Mataram cukup beragam, mulai dari manuskrip seperti buku teks, handbook, kamus, ensiklopedia dan file elektronik hingga koleksi audio-visual, meliputi kaset audio, slide dan kaset video yang juga dilengkapi dengan perangkat pembacanya. Civitas akademika Universitas Mataram dapat meminjam dan mengakses seluruh koleksi tersebut untuk 
memperluas pengetahuan dan menunjang proses pembelajaran.

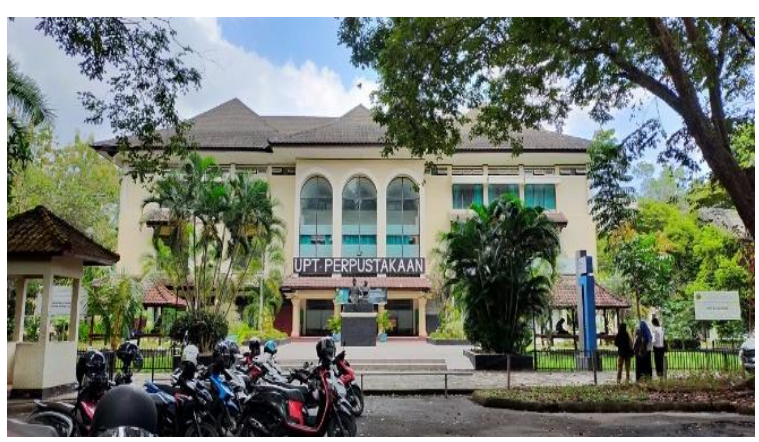

Gambar 3. Perpustakaan Universitas Mataram

Gedung perpustakaan Universitas Mataram memiliki panjang sekitar 66 meter, dan lebar 42 meter. Gedung ini dilengkapi dengan dua entrance yang menghadap ke arah utara dan selatan. Entrance sebelah utara menjadi pintu masuk utama ke dalam gedung. Sementara bagian selatan merupakan akses yang menghubungkan gedung perpustakaan dengan area rektorat. Jika dilihat dari luar, gedung perpustakaan terlihat sebagai gedung yang solid, namun ternyata di dalam gedung tersebut terdapat dua area void yang berfungsi sebagai inner courtyard. Keberadaan void ini memberikan akses pencahayaan matahari masuk ke koridor gedung. Selain void, gedung perpustakaan Universitas Mataram juga di dominasi dengan jendela-jendela yang cukup lebar. Hampir semua jendela yang ada di gedung tersebut merupakan jendela dengan kaca mati.

\section{Profil Gedung Fisipol}

Gedung ini digunakan oleh Program Studi Hubungan Internasional, Program Studi Sosiologi dan Program Studi Ilmu Komunikasi adalah gedung yang baru dibangun pada tahun 2014. Gedung ini terletak di sisi barat gedung Rektorat dan dilintasi oleh kendaraan yang keluar Unram dari pintu Barat. Gedung ini memperlihatkan salah satu ciri fisik seperti lumbung di bagian drop-off. Bangunan terdiri atas 4 lantai dan dinding bangunan diselubungi oleh ACP (Aluminum Composite Panel) bewarna abu-abu tua.

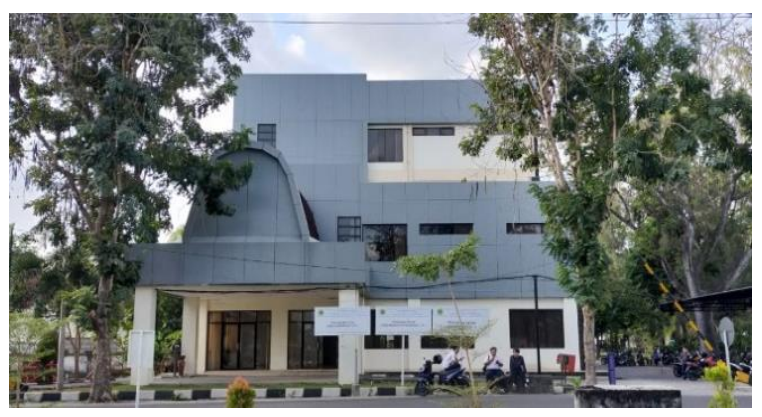

Gambar 3. Gedung Fisipol Universitas Mataram
Orientasi bangunan Gedung memanjang ke arah utara dan selatan. Pintu utama dan pintu keluar ada di sisi utara dan selatan bangunan. Sisi bagian barat dan timur adalah sisi terpanjang dan terpapar matahari. Sementara itu, di kedua sisi ini terdapat bukaan jendela terbanyak. Sisi utara dan selatan bangunan memiliki beberapa bukaan namun tidak sebanyak sisi timur dan barat.

\section{Ciri Arsitektur Vernakular dan Rendah Energi pada Gedung Perpustakaan dan Fisipol}

Beberapa faktor digunakan untuk mengevaluasi ciri vernakular dan rendah energi pada dua gedung, yaitu gedung perpustakaan dan gedung Fisipol. Faktorfaktor tersebut adalah faktor gedung dan lingkungan, bentuk bangunan, material bangunan dan struktur dan konstruksi bangunan. Hasil evaluasi gedung perpustakaan Universitas Mataram untuk kriteria arsitektur vernakular ditunjukkan pada Tabel 3.

Pada Tabel 3, gedung perpustakaan memiliki aspek vernakular lebih banyak dibandingkan dengan gedung Fisipol. Keduanya sama-sama tidak memiliki beberapa aspek vernakular pada enam point. Atap lumbung sebagai tempat penyimpanan tidak dimiliki kedua gedung walau gedung Fisipol memiliki langgam lumbung tapi hanya sebagai fungsi estetika saja. Bukaan yang kecil dan banyak tidak dimiliki kedua gedung. Keduanya memiliki bukaan yang besar dengan sisi terpanjang menghadap barat dan timur. Untuk desain pintu, mungkin penerjemahannya agak berbeda karena model pintu berbeda-beda saat ini mengikuti perkembangan zaman. Karakteristik pintu tidak menjadi masalah, akan tetapi sebaiknya disesuaikan. Material ramah lingkungan adalah material yang mudah didapatkan, tidak merusak lingkungan, dan mudah didaur ulang.

Material yang digunakan di kedua gedung tidak menggunakan material alami akan tetapi mampu bertahan lama. Material pintu dan lantai keduanya menggunakan bahan material yang sama. Pintu terbuat dari kaca dan kayu, di mana kaca bukan material ramah lingkungan. Lantai terbuat dari keramik, akan tetapi sebaiknya penggunaan keramik dapat diganti dengan material ubin yang lebih ramah lingkungan. Struktur dan konstruksi kedua gedung memiliki karakteristik yang sama. Karena bangunan membutuhkan kekuatan, maka kedua gedung menggunakan struktur dan konstruksi yang kaku (rigid) dengan kolom dan balok. Adapun atap gedung menggunakan struktur dan konstruksi yang berat; gedung perpustakaan menggunakan baja dan gedung Fisipol menggunakan atap datar (cor beton). Oleh karenanya, aspek-aspek tersebut belum diperhatikan ketika mendesain gedung perpustakaan dan gedung Fisipol. 
Aspek yang menjadi pembeda kedua gedung adalah bentuk atap. Bentuk atap gedung perpustakaan dapat menaungi dinding dan bukaan yang terdapat pada bangunan. Gedung perpustakaan menggunakan atap perisai dengan beberapa teritisan di setiap lantai. Akan tetapi, atap gedung Fisipol tidak memiliki teritisan dan perpanjangan bagian atap. Hal ini menyebabkan air hujan secara langsung dapat membasahi bagian dinding bangunan. Apabila dilihat secara sekilas, atap adalah bagian mencolok yang menajdi pembeda kedua gedung ini. cenderung tidak ramping apabila dilihat dari luar. Akan tetapi, gedung perpustakaan memiliki courtyard yang memudahkan pencahayaan dan penghawaan dapat masuk ke dalam bangunan. Selain itu, kedua gedung tidak memiliki skylight dan kurang memanfaatkan pencahayaan alami pada siang hari. Kedua gedung juga kurang memanfaatkan penghawaan alami karena desain jendela yang tertutup (tidak dapat dibuka) dan hanya mengandalkan ventilasi atas (lubang angin) sebagai pertukaran udara. Akibatnya, hampir semua ruangan

Tabel 3. Pemenuhan Kriteria Arsitektur Vernakular Gedung Perpustakaan

\begin{tabular}{|c|c|c|c|c|}
\hline \multicolumn{2}{|c|}{ Faktor-Faktor Bangunan } & Penerapan Bangunan Kampus & Perpustakaan & Fisipol \\
\hline \multirow[b]{2}{*}{ 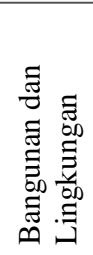 } & Orientasi bangunan & $\begin{array}{l}\text { Bukaan bangunan menghadap orientasi timur } \\
\text { dan barat }\end{array}$ & YA & YA \\
\hline & Tanggapan kontur & $\begin{array}{l}\text { Bangunan disusun mengikuti arah kontur, } \\
\text { bangunan yang kedudukannya tinggi } \\
\text { ditempatkan di tempat yang lebih tinggi (secara } \\
\text { kontur) }\end{array}$ & YA & YA \\
\hline \multirow{7}{*}{ 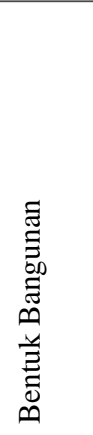 } & \multirow[t]{2}{*}{ Atap bangunan } & Lebar atap dapat melindungi dinding bangunan & YA & TIDAK \\
\hline & & Atap lumbung sebagai fungsi penyimpanan & TIDAK & TIDAK \\
\hline & Dinding bangunan & Dinding dapat melindungi bangunan & YA & YA \\
\hline & Jendela bangunan & Memiliki bukaan kecil dan banyak & TIDAK & TIDAK \\
\hline & Pintu bangunan luar & Pintu dapat dibuka dan tidak tembus pandang & TIDAK & TIDAK \\
\hline & Pintu antar ruangan & Pintu dapat digeser & TIDAK & TIDAK \\
\hline & Lantai bangunan & Ada kenaikan lantai dari area sekitar & YA & YA \\
\hline \multirow{4}{*}{ 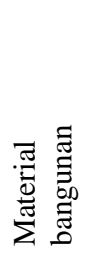 } & Atap bangunan & $\begin{array}{l}\text { Menggunakan material tidak panas dan mudah } \\
\text { didapatkan }\end{array}$ & YA & YA \\
\hline & Dinding bangunan & Menggunakan material ramah lingkungan & YA & YA \\
\hline & Pintu bangunan & Menggunakan material ramah lingkungan & TIDAK & TIDAK \\
\hline & Lantai bangunan & Menggunakan material ramah lingkungan & TIDAK & TIDAK \\
\hline \multirow{2}{*}{ 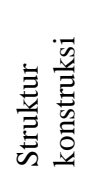 } & Atap (beruga') & $\begin{array}{l}\text { Menggunakan konstruksi atap ringan dengan } \\
\text { bentuk perisai }\end{array}$ & TIDAK & TIDAK \\
\hline & $\begin{array}{l}\text { Kolom-balok } \\
\text { (beruga') }\end{array}$ & $\begin{array}{l}\text { Menggunakan konstruksi ringan yang tidak } \\
\text { kaku }\end{array}$ & TIDAK & TIDAK \\
\hline
\end{tabular}

Sementara itu, untuk kajian rendah energi pada gedung perpustakaan dan Fisipol dapat dilihat pada Tabel 4. Secara sekilas, gedung perpustakaan memiliki aspek rendah energi lebih banyak dibandingkan dengan gedung Fisipol. Ada 6 dari 14 aspek yang harus dibenahi oleh gedung perpustakaan agar menjadi bangunan rendah energi. Akan tetapi, gedung Fisipol memerlukan perbaikan 12 dari 14 aspek.

Persamaan ketiadaan aspek rendah energi di kedua gedung dapat dilihat dari 6 aspek. Kedua gedung menggunakan penghawaan buatan. Orientasi gedung juga tidak sesuai dengan prinsip bangunan hemat energi. Orientasi gedung perpustakaan dan gedung Fisipol mengacu arah utara-selatan sehingga sisi terpanjang bangunan berada di sisi timur-barat. Hal ini menyebabkan panas matahari dapat diserap oleh gedung secara maksimal sehingga penggunaan pengahawaan buatan akan semakin meningkat terutama pada siang hari. 


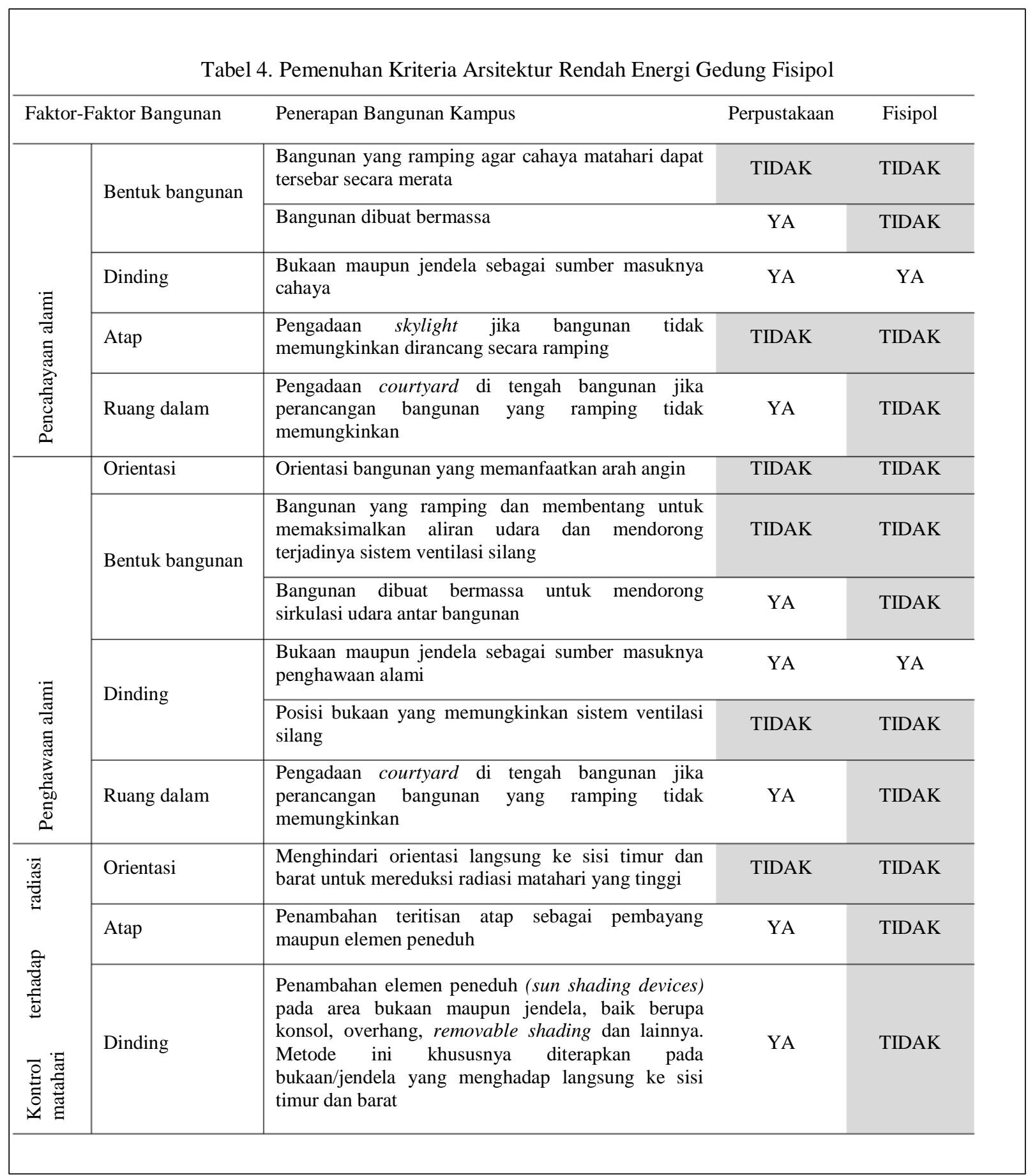

Selain itu, gedung Fisipol tidak memenuhi kriteria bangunan ramah lingkungan lainnya. Gedung Fisipol termasuk bangunan bermassa besar dengan ukuran 45 x 19 meter. Gedung ini juga tidak memiliki area courtyard yang seharusnya dirancang untuk memasukkan pencahayaan dan penghawaan alami ke dalam gedung. Terkait pemanfaatan arah angin, gedung Fisipol ini telah memiliki jumlah bukaan yang cukup di sisi timur-barat untuk menangkap angin. Sayangnya penghawaan dalam bangunan belum dapat optimal karena layout ruang dan posisi dinding-dinding ruang dalam. Jika dilihat dari atas, hampir keseluruhan area atap bangunan menggunakan atap dak beton. Bentuk atap menyerupai lumbung hanya digunakan pada titik drop-off penumpang di area pintu masuk. Kondisi ini tentunya kurang sesuai untuk merespon iklim Indonesia yang memiliki curah hujan yang tinggi. Penggunaan atap dak beton juga mengakibatkan bangunan tidak memiliki overstek/teritisan atap yang dapat berfungsi untuk mereduksi intensitas radiasi matahari yang masuk ke dalam bangunan. Penggunaan atap massif yang tidak disertai dengan penggunaan skylight juga menjadi salah satu factor yang menyebabkan pencahayaan alami tidak dapat tersebar merata ke dalam bangunan. 


\section{Kesimpulan}

Secara umum, beberapa kriteria arsitektur vernakular dan ramah lingkungan belum dipenuhi oleh kedua gedung. Gedung perpustakaan yang sebelumnya diinterpretasikan memiliki semua kriteria arsitektur vernakular dan ramah lingkungan karena karena merupakan bangunan lama, ternyata belum dapat memenuhi semua kriteria tersebut. Sementara itu, gedung Fisipol yang diinterpretasikan memiliki semua kriteria vernakular dan ramah lingkungan karena merupakan gedung baru, ternyata jauh lebih rendah penerapannya di dalam desain gedung. Gedung perpustakaan merepresentasikan kriteria arsitektur ramah lingkungan lebih baik dibandingkan dengan gedung Fisipol. Akan tetapi, untuk kriteria arsitektur vernakular keduanya hampir sama.

Untuk harapan ke depan, desain gedung baru pada bangunan pendidikan terutama di Universitas Mataram dapat menggunakan kriteria-kriteria arsitektur vernakular dan ramah lingkungan sebagai patokan utama dalam desain. Arsitektur vernakular setempat seharusnya dilestarikan agar menjadi identitas kampus sesuai dengan tempat asal kampus berada. Arsitektur ramah lingkungan sebagai bagian dari tugas dan tanggung jawab seorang arsitek untuk memenuhi persyaratan kualitas bangunan dan kenyamanan pengguna. Penelitian ini masih banyak kekurangan dan membutuhkan banyak kajian serupa.

\section{Daftar Pustaka}

Amira, K. (2021). Biaya Kuliah di UNUD. BeasiswaId.Net. https://beasiswa-id.net/biaya-kuliah-diunud/

Anggraeny, N. F., Antariksa, \& Suryasari, N. (2011). Perubahan Bentuk Bangunan Bale Tani di Dusun Sade Lombok Tengah. Tesa, 9(2), 82-94.

Asyraf, M. H., \& Budi, B. S. (2017). Analisis Penulis Mengenai Akulturasi Budaya pada Aula Timur ITB. Seminar Ikatan Peneliti Lingkungan Binaan Indonesia (IPLBI), A279-A284. https://doi.org/10.32315/sem.1.a279

Auliya, T., Surjono, \& Antariksa. (2009). Permukiman Tradisional Suku Sasak di Dusun Senaru. Arsitektur E-Journal, 2(2), 120-129.

Dober, R. P. (1991). The Society for College and University Planning: Campus Design.

Ghotbi, A. A. (2008). The Concept of Identity and Modern Iranian Architecture. Aeiine Khial Journal, 10.

Krisna, R., Antariksa, \& Rini Dwi Ari, I. (2005). Studi Pelestarian Kawasan Budaya di Dusun Sade Kabupaten Lombok Tengah. Jurnal Plannit, 3(2), 124-133.
Papanek, V. (1995). The Green Imperative: Ecology and Ethics in Design and Architecture. Thames and Hudson.

Pearson, D. (1994). Earth to Spirit. London: Chronicle Books.

Pujianto, F., \& Yenny, G. (2017). Berugaq Sebagai Identitas Arsitektur Desa Tanah Petak Daye, Lombok Utara. Media Matrasain, 14(1), 12-22.

Raharja, I.G.M. (2010). Konsep Ruang yang Mendasari Desain Interior Rumah Tinggal Tradisional Bali Madya/Bali Arya II. Jurnal ISI Denpasar, 8, 1-3.

Sitorus, Y. F. E. (2017). Konsep Desain Atap Aula Timur dan Aula Barat Institut Teknologi Bandung. Seminar Ikatan Peneliti Lingkungan Binaan Indonesia (IPLBI), A027-A032. https://doi.org/10.32315/sem.1.a027

Suriastuti M.Z., Wahjudi D., Handoko B. (2014). Kajian Penerapan Konsep Kearifan Lokal pada Perancangan Arsitektur Balaikota Bandung, Jurnal Itenas Rekarupa, 2 (1), 128.

Torabi, Z., \& Brahman, S. (2013). Effective Factors in Shaping the Identity of Architecture. Middle-East Journal of Scientific Research, 15 (1), 106-113.

Wiranto, (1999). Arsitektur Vernakular Indonesia: Perannya Dalam Pengembangan Jati Diri. Dimensi Teknik Arsitektur, 27 (2), 15 - 20. 